軽金属 第66巻第5号 (2016)，233-239

$$
\begin{gathered}
\text { 難燃性マグネシウム合金や } \\
\text { 耐熱マグネジム合金の開発と応用 }
\end{gathered}
$$

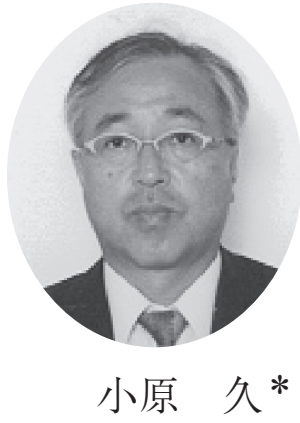

\author{
Journal of The Japan Institute of Light Metals, Vol. 66, No. 5 (2016), 233-239
}

(C) 2016 The Japan Institute of Light Metals

\title{
Development and application of flame-retardant and heat-resistant magnesium alloys
}

\author{
Hisashi OHARA*
}

Keywords: magnesium alloys, flame-retardant, heat-resistant

\section{1.はじめに}

戦後の日本におけるマグネシウム産業は，マグネシウム合 金鋳物，アルミニウム合金添加成分やチタン製錬の還元材な どとして使用されることから始まった。1954年にチタン製 錬工程から発生する四塩化マグネシウムから電解法により マグネシウムが回収され，1957年に古河マグネシウム株が 熱還元法によるマグネシウム生産を開始した。そして早くも 1960 年には東洋工業(株)（現マツダ(株）がマツダR360クーペ を発売し, トランスミッションケースなど 6 点の主要なエン ジン部品にマグネシウム合金を採用し，本格的な自動車部品 へのマグネシウム合金利用が始まることとなった。その後, 紆余曲折はあるものの日本のマグネシウム産業は図 1 に示す 通り着実な成長を続け，1988年には国内のマグネシウム総 生産能力が約 23,000 トンまで拡大することとなった。ただ, 海外とのマグネシウム生産コスト競争により徐々に国内製錬 が縮小となり，1994年に完全に生産を中止することとなっ た。しかし，国内生産とは逆にマグネシウムの需要は着実な 増加を示し，1980年には業務用ビデオカメラケース，1982 年ホンダシティターボのシリンダヘッドカバー, 1983 年ス テアリングコラム・アッパブラケット，1989年ハンドル芯 金などにマグネシウム合金が採用され，1991年には携帯電 話の筐体，1995年にノートパソコン筐体などにまで使用さ れることとなり，2007年には47,435トンの最大需要量を達 成した。その後, リーマンショックの経済不況や地産地消対 応によるマグネシウム加工拠点の海外流出などにより需要量 の減少となったが，2014年にはようやく40,290トンまで回 復することができた。この間の1999年には，国内で開発さ れたACM522耐熱マグネシウム合金によりインサイトのオ
イルパンが開発され1），2002年頃にはAE62-Ca耐熱マグネシ ウム合金製トッランスミッションケースが北米乗用車向けに 開発され ${ }^{2)}$, 欧米と同様に自動車部品の幅広いマグネシウム 化が実現することとなった。

マグネシウムは密度が約 $1.74 \mathrm{Mg} / \mathrm{m}^{3}$ と構造用金属材料とし ては最も軽量な素材であることはよく知られている。構造材 としてマグネシウムを利用する場合は, $\mathrm{Al}, \mathrm{Zn}, \mathrm{Mn}$, その他 の金属成分を添加することによりマグネシウム合金として使 用されるのが普通である。この場合の密度は, $1.3 \sim 2.0 \mathrm{Mg} /$ $\mathrm{m}^{3}$ 程度となっている。軽量化が必要な時にはマグネシウム 合金が候補材料として検討される機会も増しているものと見 られるが，まだまだ実際に採用されるケースは少ないのが現 状である。また，たとえマグネシウム合金が採用されたとし ても，その後の汎用構造材料の技術や性能向上により，容易 に代替されてしまうことも多くある。

この原因は，技術的観点では次のような事項によるものと 考えられる。

(1)他の沉用構造材料に比べ大気中でマグネシウム合金溶湯 を扱う場合には，防然対策が必要である。

(2)マグネシウム合金は, ヤング率がアルミニウム合金のほ ぼ半分程度であることから, 構造部材として必要な剛性 を得るためには専門的な設計が必要である。

(3)マグネシウム合金は基本的に標準電極電位が卑であるこ とから，他の金属材料と接触させる場合には絶縁や電解 液排除などの流電防止対策が必要である。

(4)マグネシウム合金の特性が，広く知られていない。

(5)マグネシウム合金材料についての加工技術が普及してい ない。

6材料コストが高水準にある。

\footnotetext{
*一般社団法人日本マグネシウム協会（†103-0027 東京都中央区日本橋 3-6-10） Japan Magnesium Association (3-6-10 Nihonbashi, Chuo-ku, Tokyo 103-0027) E-mail: ho01-mag@kt.rim.or.jp 受付日：平成28年2月 18 日 受理日：平成28年 3 月 8 日
} 


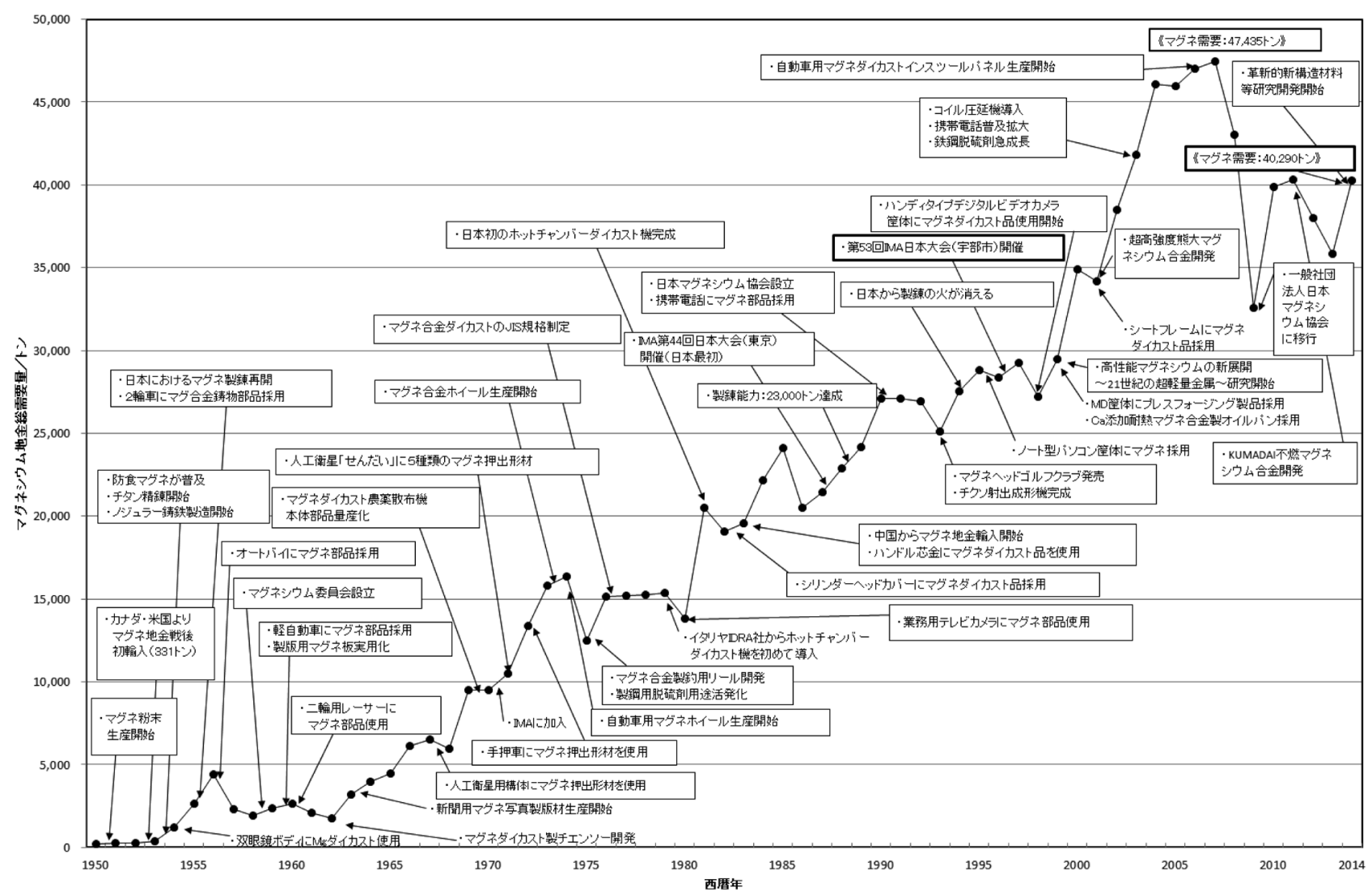

図1 日本のマグネシウム需要量の推移と製品開発の歩み

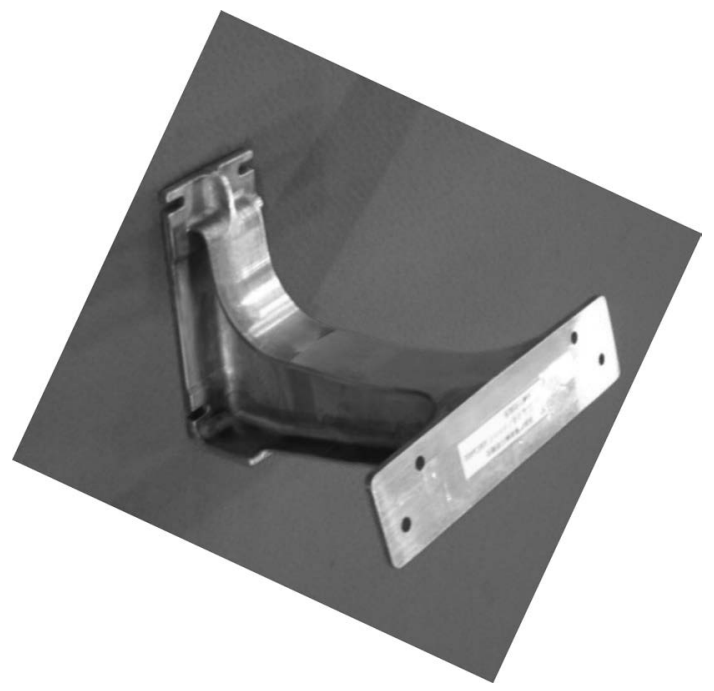

図 2 鉄道車両用荷物支持部材 : $\mathrm{AZ} 91+\mathrm{Ca}$

などが挙げられる。

しかし, 欧米などにおいては深刻化する地球温暖化の対応 策の 1 つして自動車からの排出ガスの削減が急務となって おり, 一層厳しい自動車排出ガスの規制を強化する方向にあ る。例えば，乗用車の $\mathrm{CO}_{2}$ 排ガス規制值を走行燃費で示すと 2015 年に欧州では $17.8 \mathrm{~km} / \mathrm{L}$, 日本で $16.8 \mathrm{~km} / \mathrm{L}$, 中国 $14.5 \mathrm{~km} /$ L，2016年に米国で $15.1 \mathrm{~km} / \mathrm{L}$ な゙が燃費向上目標とされて おり, 2020 年では欧州で $24.4 \mathrm{~km} / \mathrm{L}$, 日本 $20.3 \mathrm{~km} / \mathrm{L}$, 中国 $20.0 \mathrm{~km} / \mathrm{L}$ まで強化されることとなっている。さらに, 日本 や中国ではこれ以降の燃費規制目標は発表されていないもの の，2025年には欧州では 30〜 34 km/Lへの規制強化目標が提

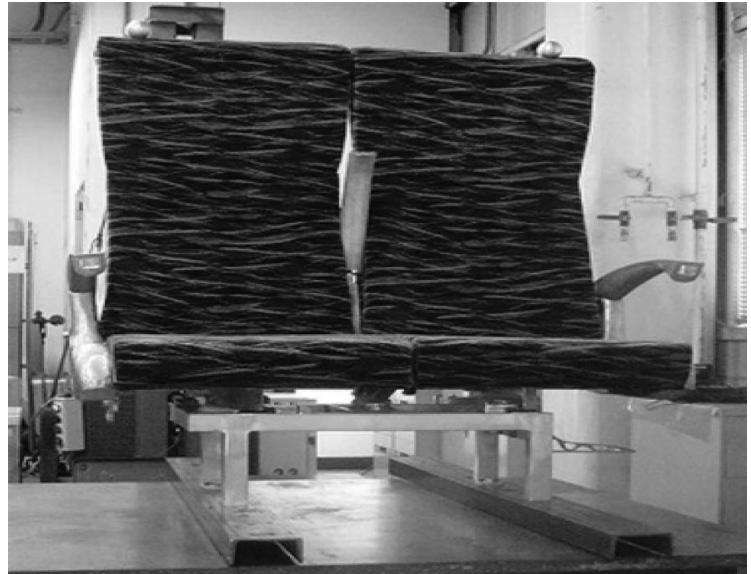

図3 鉄道車両用座席の試作

案され，米国では $23.2 \mathrm{~km} / \mathrm{L}$ の目標值が発表されている。な おこれに止まらず，欧州においては2030年に向けてより一 層排出ガスの規制が強化され続けるとも見られている。この ような，自動車に対する $\mathrm{CO}_{2}$ 排出ガス削減の目標を実現する ため自動車産業界に抏いてはエンジンの効率化, コンパクト 化, ディーゼル化, 電気自動車化, ハイブリッド化, 水素然 料電池車などの開発が進められ多様な対応が図られている。 また, 車両重量 $100 \mathrm{~kg}$ の軽量化で $1 \mathrm{~km} / \mathrm{L}$ の燃費向上につなが ると言われており, 車両重量軽量化推進のため各種材料での 対応が進められている。特に, 構造用金属材料で最も軽量な マグネシウム合金では, 自動車車体の軽量化を確実に実現す るため, 新たなマグネシウム合金の開発も進められており, その一端を紹介する。 


\section{2.＼cjkstart難燃性マグネシウム合金の開発状況}

マグネシウムについての古くからの課題は, マグネシウム 溶湯が空気中の酸素と接触すると酸化燃焼反応が起こること であり，この状況を回避するため以前から塩化物系フラック スの散布や亜硫酸ガス, $\mathrm{SF}_{6}$ ガスおよび同程度の特性を有す

Updated Horizontal Bar Testing Rig
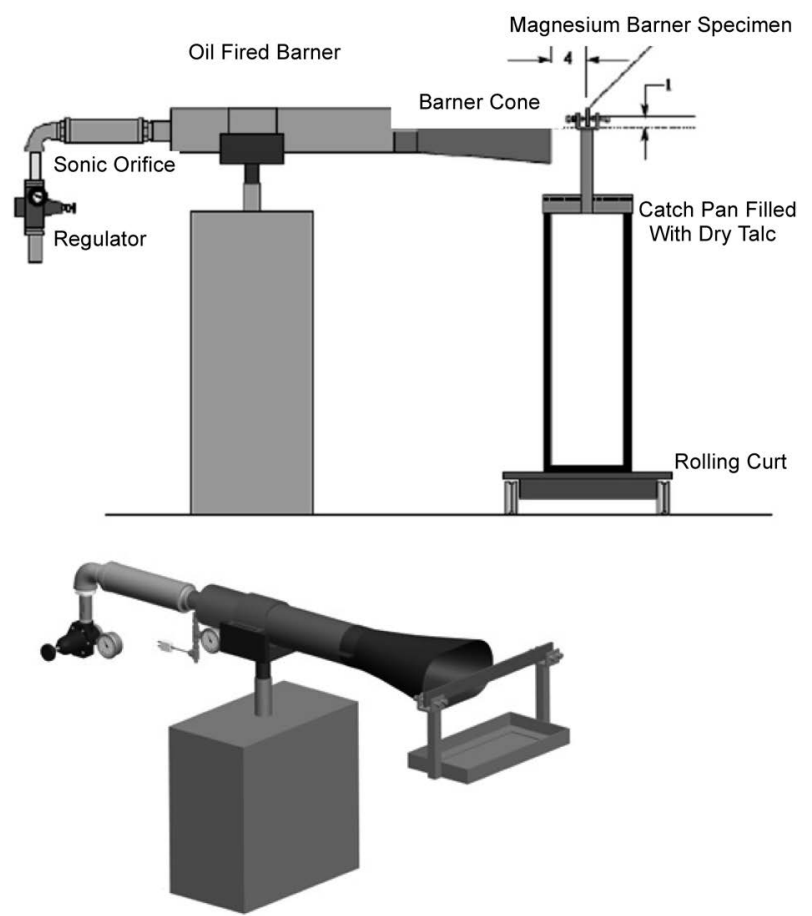

図4 米国FAAにより基準化されたマグネシウム合金の 燃焼試験方法
る環境対応防然ガスによる空気との絶縁, ダイカスト用マ グネシウム合金での $\mathrm{Ca}$ や $\mathrm{Be}$ の微量添加などの対策が実施さ

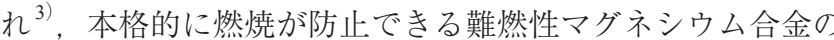
開発が期待されてきた。このなかにあって，日本，欧州並び に韓国において積極的に，難燃性マグネシウム合金の開発と 難燃性評価が行われている。

日本においては 1994 年に秋山が初めてマグネシウム合金 の難燃化を提唱し「 $\mathrm{Ca}$ 添加による難燃性 $\mathrm{Mg}$ 合金」を発表し た。AZ91ダイカスト用マグネシウム合金にCaを 0 5\%, Zn を $0.7,1.4,2.1 \%$ 添加し, 粉末化した場合のマグネシウム合金 の発火温度の変化を測定することにより, $\mathrm{Ca}$ 添加の増加に 伴い発火温度が上昇することを示した ${ }^{4)}$ 。この後, 各種既存 マグネシウム合金にCaを添加し，難燃化を図る研究が進め られている5)

また，熊本大学では $K U M A D A I$ 高強度高耐熱マグネシウム 合金が優れた難燃特性を有することが実測されるとともに， $1050^{\circ} \mathrm{C}$ の加熱を受けても発火しないKUMADAI不燃マグネシ ウム合金を開発し，自動車分野だけでなく難燃高強度高耐食 性のマグネシウム合金特性が要求される航空機分野での応用 が期待されている6)。

これらの研究開発の結果, 難燃性マグネシウム合金押出材 が高速道路のETC 遮断機の遮蔽用阻止棒に使用され, 多軸 ボール盤の多軸ヘッドなどに実用化され ${ }^{7)}$ ，高速車両では図 2 に示す難燃性マグネシウム合金ダイカスト材が荷物棚支持 材にも採用されることとなっている。また，これら実用化さ れた製品以外でも図 3 に示す鉄道車両用座席フレームや夕ー ボチャージャファン，ピストンなど各種の製品も試作される こととなっている。

欧州においては，2000年頃から地球温暖化対策の観点か ら航空機による排ガス削減とともに，エネルギーコストの削

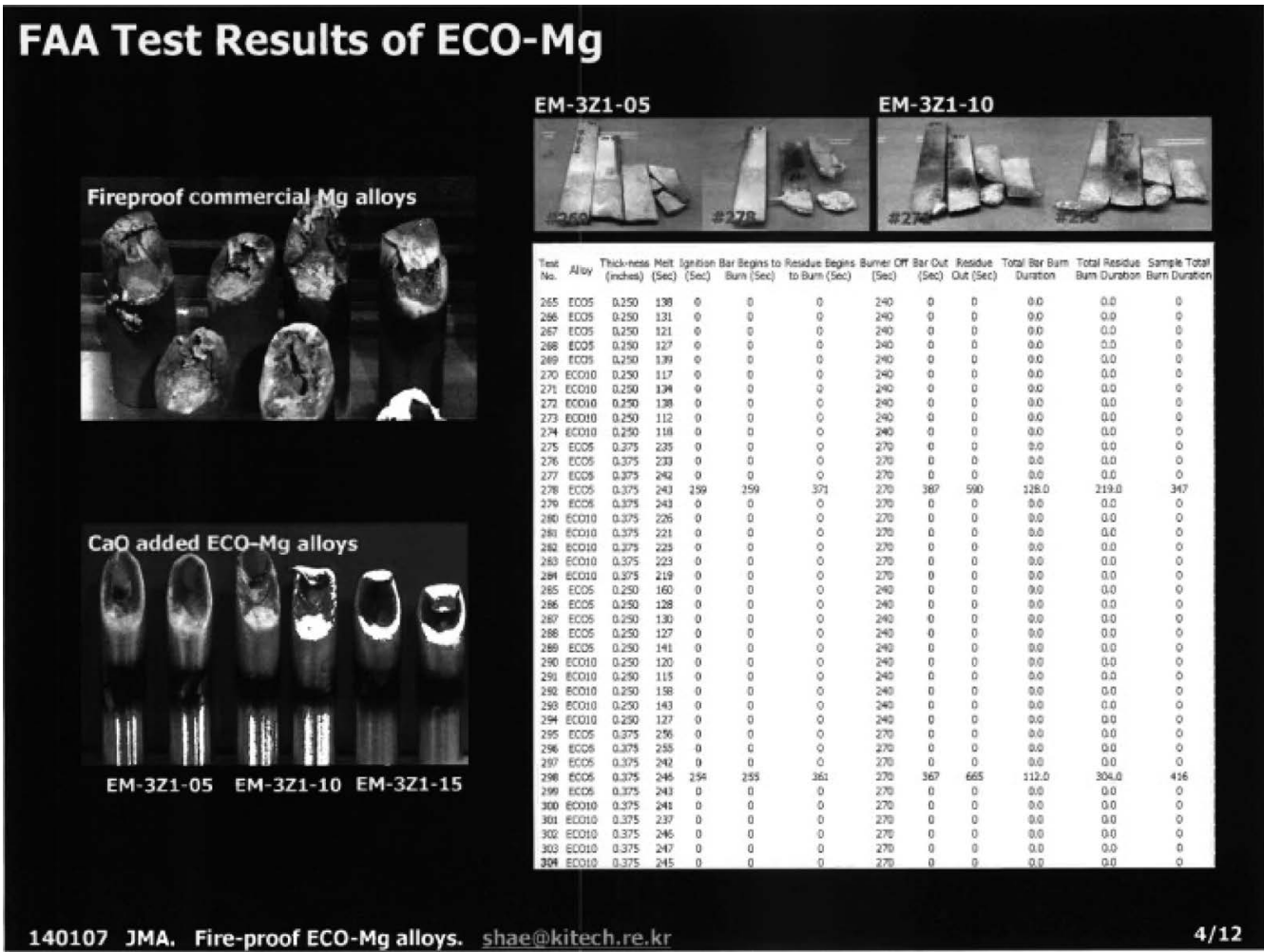

図 5 KITECH での難燃性マグネシウム合金ECO-Mgの燃焼試験結果（by S. K. Kim） 


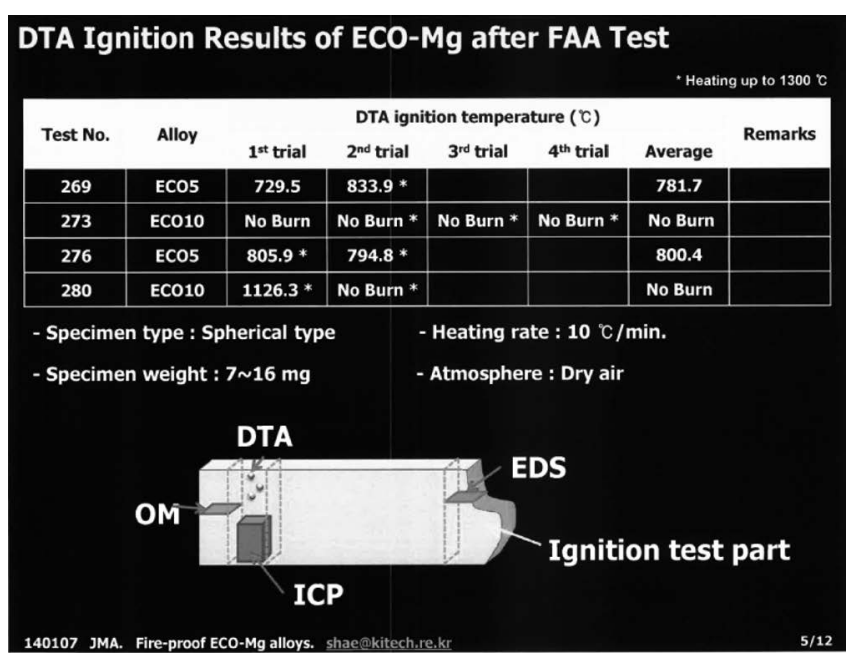

図6 KITECHが提案するFAA 試験体を用いた複合的燃 焼試験結果（by S. K. Kim）

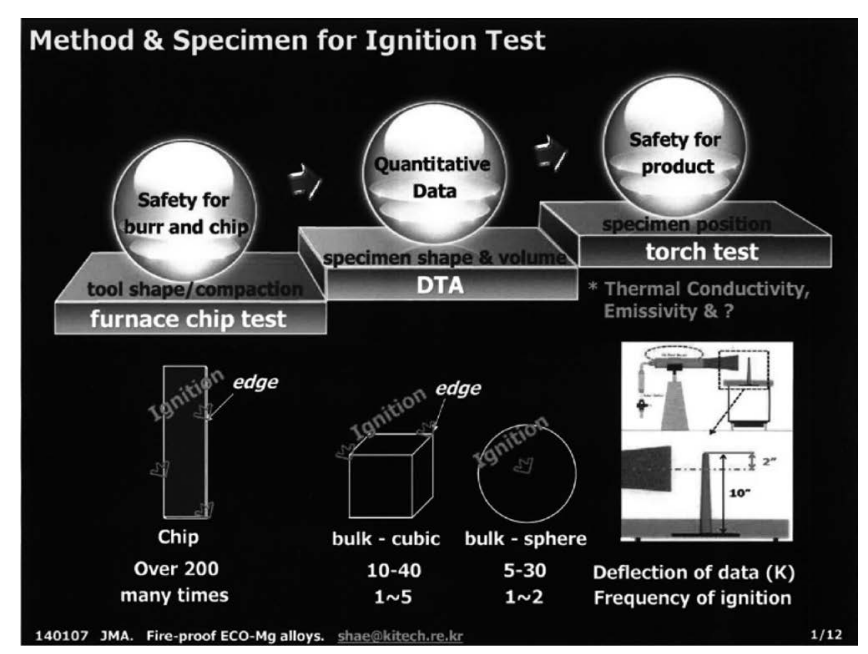

図 7 燃燒性試験のための試験体形状と試験方法（by S. K. Kim)

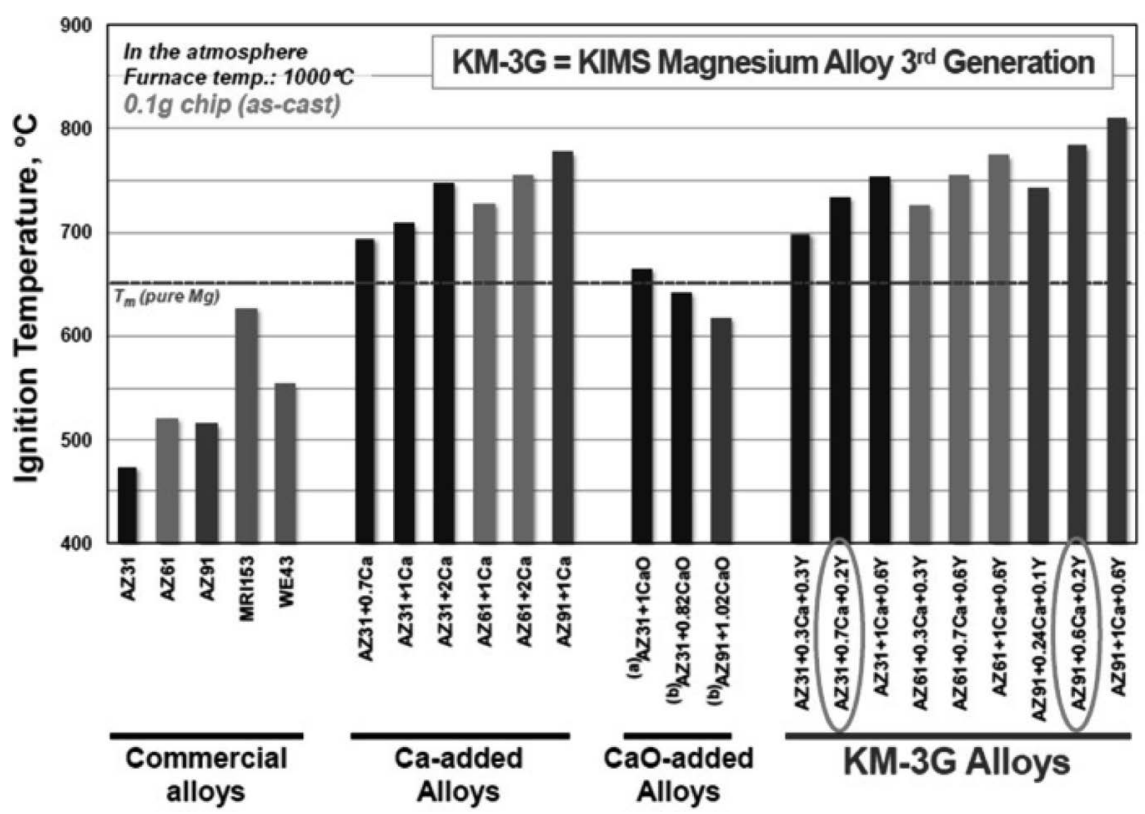

図8 韓国の KIMS で試験中の難燃マグネシウム合金（by B. S. You）

減が問題となり機体の重量軽減が検討されることとなった。 このため, 航空機内装材や装備品への耐熱高強度マグネシウ ム合金の適用が検討されたが，航空機用シートフレームにつ いてSAE規格でマグネシウム合金の使用が規制されている ことがわかり，2007年頃からこの規格改正に向けた検討が 始まり，マグネシウム合金の燃焼性を評価するための図4に 示す燃焼試験法と評価基準が確立することとなった。評価基 準は，長さ 20 インチ×幅 1.5 インチ×厚さ 0.25 インチの長方 形試験体を約 $930^{\circ} \mathrm{C}$ のイイバーナで 4 分間加熱し，加熱終 了後3 分以内に自己消火し，重量損失が初期重量の $10 \%$ 以内 であることとなっている ${ }^{8) \sim 10)}$

韓国においては，2つの研究機関でそれぞれに難燃性マグ ネシウム合金の開発が進められ，現在に至っている。その 1 つは, Korea Institute of Industrial Technology（KITECH） Shae K. Kimらで, 2005 年にマグネシウム合金への $\mathrm{CaO}$ の添加に よる発火特性効果について研究成果を発表 ${ }^{11)}$ し, それ以降 $\mathrm{AZ31}, \mathrm{AM} 60, \mathrm{AZ} 91$ などの汎用マグネシウム合金に $\mathrm{CaO}$ を添
加し ECO-Mg として機械的性質や発火温度への影響を調査す るとともに，各種耐熱合金との発火温度の比較デー夕などを 提供している。さらには，構造用マグネシウム合金素材に対 する燃焼性測定試験方法についても検討を行い, 従来から実 施されている各種マグネシウム粉末を用いた発火温度測定だ けでなく, 図5の円錐棒状試験体での発火性試験を始め, 図 6 に示す長方形の試験体による発火温度測定や組織観察, 小 形状個体を切出した発火試験など複合試験による性能評価を 提案している。また, 図7にKITECHが提案する各種試験体 形状での燃焼性試験法を示す。

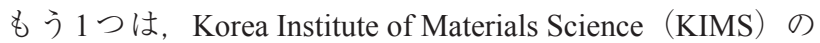
Bong Sun Youらの研究であり，2000年にマグネシウム合金へ の Ca 添加による酸化特性の効果について研究発表 ${ }^{12)}$ し, 最 近では図 8 に示す通り既存の各種マグネシウム合金にCa と Y を添加したマグネシウム合金の発火温度の上昇と共に, 図9 に示す通り，機械的性質への影響を発表している。図10に, 推奨する $\mathrm{Ca}, \mathrm{Y}$ 添加の変化による発火温度への影響を示す。 


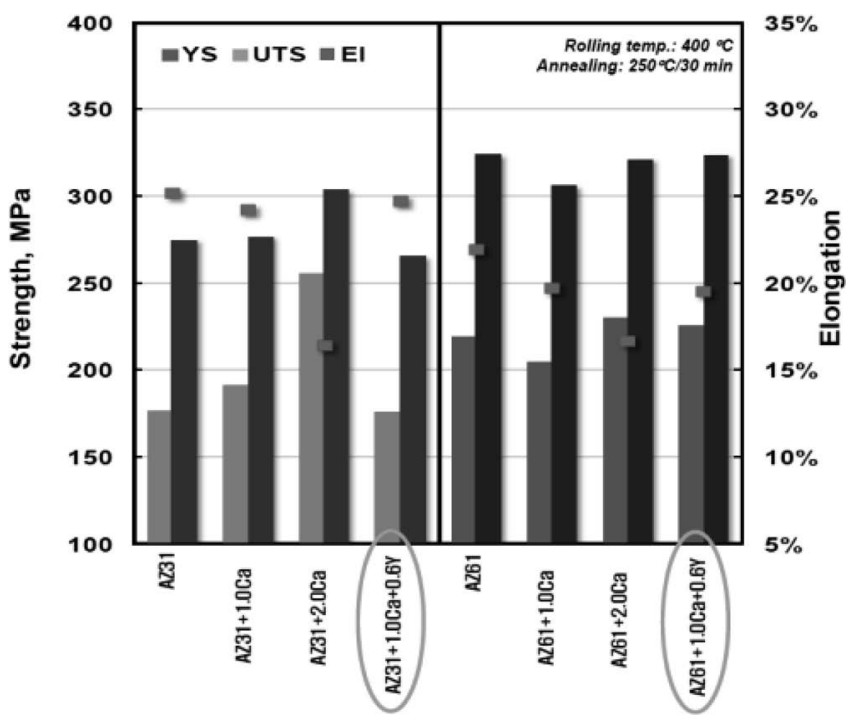

図 9 難燃マグネシウム合金の機械的性質比較（by B. S. You)

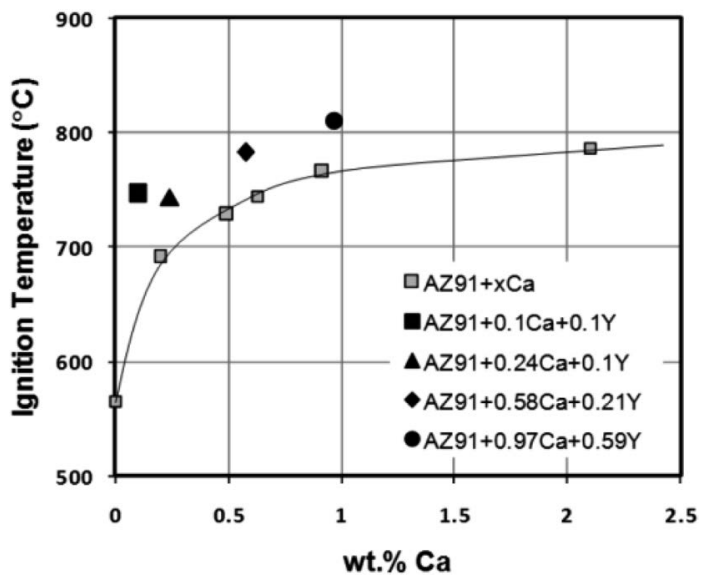

図 $10 \mathrm{Ca}, \mathrm{Y}$ 添加量の変化による発火温度への影響（by B. S. You)

\section{3. 耐熱マグネシウム合金の開発状況と適用}

輸送機器の軽量化では車体重量の軽量化だけでなく駆動機 器部品の軽量化も重要な課題であり, パワートレイン分野で のマグネシウム合金の応用が期待されている。このため，各 国で耐熱性やクリープ特性に優れたマグネシウム合金の開発 が進められている。

世界的には，日本での開発も含め表1のような耐熱マグ ネシウム合金が開発され，実用化されている。1970年に開 発された $\mathrm{Mg}-\mathrm{Al}-\mathrm{Si}$ 系の AS21 合金は, ドイッのVolksWorgen 社向けに提供され，その後同系統の AS31 がベンッ車のオー トトランスミッションに採用されている。1987年頃にイギ リスの Magnesium Elektron社が開発した Mg-Y-RE-Nd-Zr 系 WE54, WE43 は高強度耐熱マグネシウム合金としてパワート レイン部品やトランスミッションなどに使用され，航空機 シートフレームなどの内装部品への応用が検討されている。 Mg-Al-RE系の AE42 は1995年頃に開発されているが，米国 のUSCAR 自動車軽量化プロジェクトの中でエンジンクレー ドルとして GM-コルベットZ 06 に採用されアルミニウム合 金に比べ35\%の軽量化を実現している。MRI153マグネシウ
表1世界的に開発された代表的な耐熱マグネシウム 合金例

\begin{tabular}{|c|c|c|}
\hline 年 & 合金名 & 合金系 \\
\hline 1970 & AS21耐熱合金 & $\mathrm{Mg}-\mathrm{Al}-\mathrm{Si}$ 系 \\
\hline 1987 頃 & WE54, WE43 合金 & Mg-Y-RE系 \\
\hline 1995 頃 & AE42 合金 & Mg-Al-RE系 \\
\hline 1999 & ACM522 合金 & $\mathrm{Mg}-\mathrm{Al}-\mathrm{Ca}-\mathrm{RE}$ 系 \\
\hline 2000 & MRI153 合金 & $\mathrm{Mg}-\mathrm{Al}-\mathrm{Ca}-\mathrm{Sr}$ 系 \\
\hline 2001 & $\begin{array}{l}K U M A D A I \text { 耐熱マグネシウム } \\
\text { 合金 }\end{array}$ & $\mathrm{Mg}-\mathrm{Zn}-\mathrm{Y}$ 系 \\
\hline 2001 & AJ51, AJ52 合金 & $\mathrm{Mg}-\mathrm{Al}-\mathrm{Sr}$ 系 \\
\hline 2002 & AE62-Ca 合金 & $\mathrm{Mg}-\mathrm{Al}-\mathrm{RE}-\mathrm{Ca}$ 系 \\
\hline 2003 & Elektron21 合金 & $\mathrm{Mg}-\mathrm{RE}-\mathrm{Zn}-\mathrm{Zr}$ 系 \\
\hline
\end{tabular}

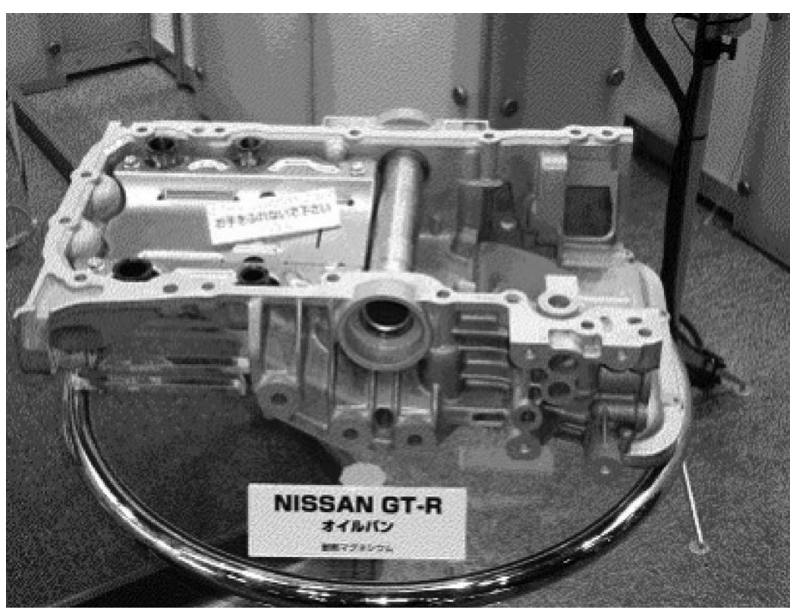

図11 日産自動車 オイルパン：MRI153合金

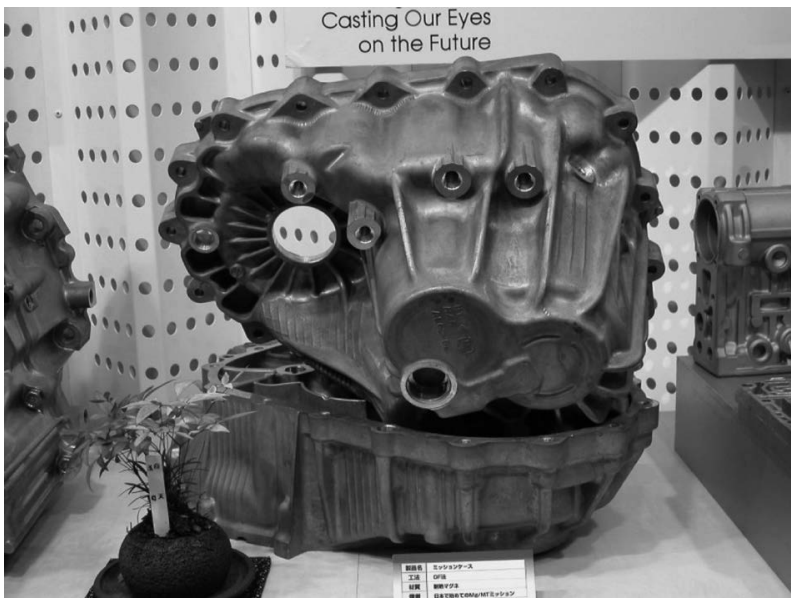

図12 ホンダトランスミッション：AEX631 合金（Mg$6 \% \mathrm{Al}-3 \% \mathrm{RE}-1 \% \mathrm{Ca}-0.5 \% \mathrm{Zn}$ )

ム合金は, イスラエルで開発された耐熱マグネシウム合金 であるが，図11に示すNISSANスカイラインGTRのオイル パンに採用され特性を発揮している。2001年に公開された Mg-Al-Sr系の AJ51, AJ52 マグネシウム合金は, AJ62マグネ シウム合金として BMW社が開発した直列 6 気筒アルミニウ ム/マグネシウム複合エンジンのベッドプレートとして採用 され，従来のアルミニウム合金エンジンに比べ $25 \%$ の軽量 
表2 日本国内における耐熱マグネシウム合金の特許公開例

\begin{tabular}{|c|c|c|c|c|c|}
\hline 番号 & 年 & 番号 & 出願者 & タイトル & 合金種 \\
\hline 1 & 1993年 & 平 $5-33096$ & トヨ夕自動車(侏) & 耐熱マグネシウム合金 & $\mathrm{Mg}-1.0 \sim 6.0 \% \mathrm{Al}-1.0 \sim 6.0 \% \mathrm{Zn}-0.2 \sim 3.0 \% \mathrm{RE}$ \\
\hline 2 & & 平 $5-171333$ & トヨ夕自動車侏) & $\begin{array}{l}\text { 耐熱性，耐食性抢よび鋳造性に優れたマグネシ } \\
\text { ウム合金 }\end{array}$ & $\begin{array}{l}\mathrm{Mg}-1.0 \sim 6.0 \% \mathrm{Zn}-0.1 \sim 2.0 \% \mathrm{RE}-0.1 \sim 2.0 \% \mathrm{Zr}-0.1 \sim 3.0 \% \mathrm{Si}- \\
0.1 \sim 6.0 \% \mathrm{Al}\end{array}$ \\
\hline 3 & 1994年 & 平 $6-49580$ & 三井金属工業(侏) & $\begin{array}{l}\text { ガドリニウム及びサマリウムを含有する高強度 } \\
\text { マグネシウム合金 }\end{array}$ & $\mathrm{Mg}-4 \sim 25 \%(\mathrm{Gd}-\mathrm{Sm})-0.8 \sim 5 \%(\mathrm{Ca}, \mathrm{Y}, \mathrm{Sc}, \mathrm{La})-2 \%(\mathrm{Zr}, \mathrm{Mn})$ \\
\hline 4 & & 平 6-172948 & トヨ夕自動車(侏) & 耐熱マグネシウム合金の製造方法 & $\mathrm{Mg}-3.0 \sim 10.0 \% \mathrm{Al}-6.0 \% \mathrm{Zn}-3.0 \% \mathrm{RE}-1 \% \mathrm{Mn}$ \\
\hline 5 & & 平 $6-256883$ & (侏神戸製鋼所 & 優れたクリープ強度を有するマグネシウム合金 & $\mathrm{Mg}-2.0 \sim 12.0 \% \mathrm{Al}-2.0 \% \mathrm{Mn}-4.0 \% \mathrm{Zn}$ \\
\hline 6 & 1995年 & 平 7-11371 & トヨ夕自動車秼) & 耐熱マグネシウム合金 & $\mathrm{Mg}-1.0 \sim 3.0 \% \mathrm{Al}-0.25 \sim 3.0 \% \mathrm{Zn}-0.5 \sim 4.0 \% \mathrm{RE}$ \\
\hline 7 & & 平 $7-11372$ & 宇部興産(株) & $\begin{array}{l}\text { 高温クリープ強度抢よび鞎性に優れたマグネシ } \\
\text { ウム合金 }\end{array}$ & $\mathrm{Mg}-1.0 \sim 6.5 \% \mathrm{Al}-0.5 \sim 1.5 \% \mathrm{Si}-0.001 \sim 0.075 \% \mathrm{Co}$ \\
\hline 8 & & 平 $7-11373$ & 宇部興産侏) & 耐熱マグネシウム合金 & $\mathrm{Mg}-1.0 \sim 6.5 \% \mathrm{Al}-0.5 \sim 1.65 \% \mathrm{Si}-0.001 \sim 1.05 \% \mathrm{Sb}$ \\
\hline 9 & & 平 $7-11374$ & 宇部興産(侏) & マグネシウム合金 & $\mathrm{Mg}-1.5 \sim 10.0 \% \mathrm{Al}-2.0 \% \mathrm{RE}-0.25 \sim 5.5 \% \mathrm{Ca}-0.2 \sim 2.5 \%(\mathrm{Cu}, \mathrm{Zn})$ \\
\hline 10 & & 平 $7-34172$ & トヨ夕自動車(株) & ダイカスト用マグネシウム合金 & $\mathrm{Mg}-0.5 \sim 2.0 \% \mathrm{Ag}-0.5 \sim 3.0 \% \mathrm{Ca}-0.2 \sim 0.7 \% \mathrm{Mn}$ \\
\hline 11 & & 平 7-331375 & トヨタ自動車(侏) & 鋳造用耐熱マグネシウム合金 & $\begin{array}{l}\mathrm{Mg}-1 \sim 3.5 \% \mathrm{Al}-0.25 \sim 3.5 \% \mathrm{Zn}-0.5 \sim 4.0 \% \mathrm{RE}-0.1 \sim 1.0 \% \mathrm{Mn}- \\
0.1 \sim 1.0 \% \mathrm{Ca}\end{array}$ \\
\hline 12 & 1996年 & 平 $8-81728$ & 宇部興産(株) & $\begin{array}{l}\text { 耐クリープ性，耐食性を有するマグネシウム合 } \\
\text { 金 }\end{array}$ & $\mathrm{Mg}-4.0 \sim 15.0 \% \mathrm{Zn}-0.5 \sim 3.0 \% \mathrm{Si}-0.5 \sim 8.0 \% \mathrm{Al}$ \\
\hline 13 & 1997年 & 平 9-256099 & 株豊田中央研究所 & 耐熱マグネシウム合金 & $\begin{array}{l}\mathrm{Mg}-1.0 \sim 6.0 \% \mathrm{Zn}-0.5 \sim 3.0 \% \mathrm{Ca}-0.4 \sim 1.0 \% \mathrm{Zr}-1.5 \sim 2.7 \% \mathrm{RE} \\
(-2.0 \% \mathrm{Al}-1.0 \% \mathrm{Mn})\end{array}$ \\
\hline 14 & & 平 9-291332 & 本田技研工業(株) & 耐熱性マグネシウム合金 & $\mathrm{Mg}-4.5 \sim 10 \% \mathrm{Al}-0.1 \sim 3 \% \mathrm{Ca}-1 \sim 3 \% \mathrm{RE}-0.3 \sim 1 \% \mathrm{Mn}$ \\
\hline 15 & 1998年 & 平 $10-324941$ & アイシン高丘(侏) & $\begin{array}{l}\text { 優れた高温特性とダイカスト鋳造性を有するマ } \\
\text { グネシウム合金 }\end{array}$ & $\mathrm{Mg}-2 \sim 9 \% \mathrm{Al}-6 \sim 12 \% \mathrm{Zn}-0.1 \sim 2.0 \% \mathrm{Ca}-0.2 \sim 0.5 \% \mathrm{Mn}$ \\
\hline 16 & 1999年 & 平 $11-323474$ & マツダ(株) & マグネシウム鋳物部材 & $\mathrm{Mg}-5 \sim 10 \% \mathrm{Al}-0.2 \sim 1 \% \mathrm{Si}-0.05 \sim 0.50 \% \mathrm{Ca}$ \\
\hline 17 & 2000 年 & 2000-319744 & $\begin{array}{l}\text { ゼネラル・モーターズ・コー } \\
\text { ポレーション }\end{array}$ & 耐クリープマグネシウム合金のダイカスト & $\mathrm{Mg}-3 \sim 6 \% \mathrm{Al}-1.7 \sim 3.3 \% \mathrm{Ca}-0.2 \% \mathrm{Sr}$ \\
\hline 18 & 2001 年 & 2001-107171 & (侏)日本製鋼所 & $\begin{array}{l}\text { 耐熱性と鋳造性に優れたマグネシウム合金およ } \\
\text { びグネジ会耐熱部材 }\end{array}$ & $\begin{array}{l}\mathrm{Mg}-4.5 \sim 7.4 \% \mathrm{Al}-1.5 \sim 4.4 \% \mathrm{Ca}-0.2 \sim 1.0 \% \mathrm{Mn}-10 \sim 1000 \mathrm{ppmBa} \\
(-0.5 \% \mathrm{Si}-0.5 \% \mathrm{Zn})\end{array}$ \\
\hline 19 & 2002 年 & $2002-327231$ & 三菱アルミニウム侏) & $\begin{array}{l}\text { 耐熱マグネシウム合金鋳造品拉よびその製造方 } \\
\text { 法 }\end{array}$ & $\mathrm{Mg}-1.5 \sim 6 \% \mathrm{Al}-0.5 \sim 3 \% \mathrm{Ca}-0.21 \sim 1 \% \mathrm{Sr}-0.1 \sim 1 \% \mathrm{Mn}$ \\
\hline 20 & 2003年 & $2003-55728$ & (珠)豊田中央研究所 & 耐熱マグネシウムム合金 & $\mathrm{Mg}-12 \%$ 以上 $\mathrm{Al}-\mathrm{RE}-(\mathrm{Li}, \mathrm{Cu}, \mathrm{Si}, \mathrm{Zn}, \mathrm{Ti})-2 \% \mathrm{Mn}-\mathrm{Be}$ \\
\hline 21 & 2004年 & $2004-232060$ & (侏)豊田自動織機 & $\begin{array}{l}\text { 鋳造用耐熱マグネシウム合金扰よび耐熱マグネ } \\
\text { シウムム合鋳物 }\end{array}$ & $\mathrm{Mg}-1 \sim 15 \% \mathrm{Ca}-3 \sim 24 \% \mathrm{Al} \quad(4 \leqq \mathrm{Ca}+\mathrm{Al} \leqq 25)$ \\
\hline 22 & & $2004-238676$ & $\begin{array}{l}\text { デッドシーマグネシウムエル } \\
\text { ティーディー }\end{array}$ & マグネシウム合金 & $\begin{array}{l}\mathrm{Mg}-4.7 \sim 7.3 \% \mathrm{Al}-0.17 \sim 0.60 \% \mathrm{Mn}-0.0 \sim 0.8 \% \mathrm{Zn}-1.8 \sim \\
3.2 \% \mathrm{Ca}-0.3 \sim 2.2 \% \mathrm{Sn}-0.0 \sim 0.5 \% \mathrm{Sr}\end{array}$ \\
\hline 23 & & 2004-238678 & $\begin{array}{l}\text { デッドシーマグネシウムエル } \\
\text { ティーディー }\end{array}$ & マグネシウム合金 & $\begin{array}{l}\mathrm{Mg}-4.8 \sim 9.2 \% \mathrm{Al}-0.08 \sim 0.38 \% \mathrm{Mn}-0.00 \sim 0.9 \% \mathrm{Zn}-0.2 \sim \\
1.2 \% \mathrm{Ca}-0.05 \sim 1.4 \% \mathrm{Sr}-0.00 \sim 0.8 \% \mathrm{RE}(-0.02 \% \mathrm{Zr}-0.001 \% \mathrm{Be})\end{array}$ \\
\hline 24 & & $2004-277761$ & アイシン精機株) & $\begin{array}{l}\text { 高強度ダイカスト用耐クリープマグネシウム合 } \\
\text { 金 }\end{array}$ & $\begin{array}{l}\mathrm{Mg}-4.0 \sim 9.0 \% \mathrm{Al}-0.8 \sim 2.0 \% \mathrm{Si}-0.1 \sim 1.3 \% \mathrm{Ca}-0.01 \sim 1.5 \% \mathrm{RE}- \\
1.2 \% \mathrm{Mn}-0.1 \% \mathrm{Zn}-0.5 \% \mathrm{Sr}\end{array}$ \\
\hline 25 & 2005 年 & 2005-113260 & トヨ夕自動車(怢) & $\begin{array}{l}\text { ダイカスト用耐熱マグネシウム合金抄よび同合 } \\
\text { 金のダイカスト }\end{array}$ & $\begin{array}{l}\mathrm{Mg}-6 \sim 10 \% \mathrm{Al}-1.8 \sim 5 \% \mathrm{Ca}-0.05 \sim 1.0 \% \mathrm{Sr}-0.1 \sim 0.6 \% \mathrm{Mn} \\
(-0.1 \sim 3 \% \mathrm{RE})\end{array}$ \\
\hline 26 & & 2005-120449 & (侏豊田中央研究所 & $\begin{array}{l}\text { 鋳造用耐熱マグネシウム合金とマグネシウム合 } \\
\text { 金製鋳物およびその製造方法 }\end{array}$ & $\mathrm{Mg}-0.2 \sim 3 \% \mathrm{Ca}-1 \sim 4 \% \mathrm{RE}-1 \% \mathrm{Zn}-0.1 \sim 1 \% \mathrm{Sr}-0.3 \sim 1 \%(\mathrm{Zr}, \mathrm{Mn})$ \\
\hline 27 & & $2005-179776$ & 碀日立製作所 & マグネシウム合金 & $\mathrm{Mg}-10 \sim 15 \% \mathrm{Al}-0.5 \sim 10 \% \mathrm{Sn}-0.1 \sim 3 \% \mathrm{Y}-0.1 \sim 1 \% \mathrm{Mn}$ \\
\hline 28 & & 2005-187894 & 三菱アルミニウム侏) & 耐熱マグネシウム合金鋳造品 & $\begin{array}{l}\mathrm{Mg}-1.5 \sim 6 \% \mathrm{Al}-0.3 \sim 3 \% \mathrm{Ca}-0.1 \sim 1 \% \mathrm{Mn}-0.21 \sim 1.0 \% \mathrm{Sr}-1 \sim \\
100 \mathrm{ppmBe}(-0.1 \sim 1 \% \mathrm{Si}-0.2 \sim 1.0 \% \mathrm{Zn})\end{array}$ \\
\hline 29 & & 2005-187895 & 三菱アルミニウム(秼) & 耐熱マグネシウム合金鋳造品 & $\begin{array}{l}\mathrm{Mg}-1.5 \sim 6 \% \mathrm{Al}-0.3 \sim 3 \% \mathrm{Ca}-0.1 \sim 1 \% \mathrm{Mn}-0.01 \sim 1 \% \mathrm{Sr}-0.1 \sim \\
3 \% \mathrm{La}-0.1 \sim 3 \% \mathrm{Ce}-0.1 \sim 3 \% \mathrm{Nd}(-0.1 \sim 1 \% \mathrm{Si}-0.2 \sim 1 \% \mathrm{Zn})\end{array}$ \\
\hline 30 & & 2005-187896 & 三菱アルミニウム(侏) & 耐熱マグネシウム合金鋳造品 & $\begin{array}{l}\mathrm{Mg}-1.5 \sim 6 \% \mathrm{Al}-0.3 \sim 3 \% \mathrm{Ca}-0.1 \sim 1 \% \mathrm{Mn}-0.01 \sim 1 \% \mathrm{Sr}-0.1 \sim \\
3 \% \mathrm{La}-0.1 \sim 3 \% \mathrm{Ce}-0.1 \sim 3 \% \mathrm{Nd}(-0.1 \sim 1 \% \mathrm{Si}-0.2 \sim 1 \% \mathrm{Zn})\end{array}$ \\
\hline 31 & & $2005-240129$ & 三菱アルミニウム侏 & 耐熱マグネシウム合金鋳造品 & $\begin{array}{l}\mathrm{Mg}-1.5 \sim 6 \% \mathrm{Al}-0.3 \sim 3 \% \mathrm{Ca}-0.1 \sim 1 \% \mathrm{Mn}-0.21 \sim 1 \% \mathrm{Sr}-0.1 \sim \\
1 \% \mathrm{Ge}-0.1 \sim 1 \% \mathrm{~Pb}-0.1 \sim 1 \% \mathrm{Sn}-0.1 \sim 1 \% \mathrm{Ag}(-0.1 \sim 1 \% \mathrm{Si}-0.2 \sim \\
1 \% \mathrm{Zn}-1 \sim 100 \mathrm{ppmBe}-0.1 \sim 3 \% \mathrm{RE})\end{array}$ \\
\hline 32 & & 2005-240130 & 三菱アルミニウム侏) & 耐熱マグネシウム合金鋳造品 & $\begin{array}{l}\mathrm{Mg}-1.5 \sim 6 \% \mathrm{Al}-0.3 \sim 3 \% \mathrm{Ca}-0.1 \sim 1 \% \mathrm{Mn}-0.21 \sim 1 \% \mathrm{Sr}-0.1 \sim \\
1 \% \mathrm{Ge}(-0.1 \sim 1 \% \mathrm{Si}-0.2 \sim 1 \% \mathrm{Zn}-1 \sim 100 \mathrm{ppmBe}-0.1 \sim 3 \% \mathrm{RE})\end{array}$ \\
\hline 33 & 2006年 & $2006-291327$ & 三菱アルミニウム侏) & 耐熱マグネシウム合金鋳造品 & $\mathrm{Mg}-6.1 \sim 8 \% \mathrm{Al}-0.5 \sim 1.8 \% \mathrm{Ca}-0.1 \sim 1 \% \mathrm{Sr}-0.1 \sim 0.5 \% \mathrm{Mn}$ \\
\hline 34 & 2007年 & $2007-70688$ & (独) 産業技術総合研究所 & $\begin{array}{l}\text { 熱間加工により作製される耐熱マグネシウム合 } \\
\text { 金及びその製造方法 }\end{array}$ & $\mathrm{Mg}-\mathrm{Al}-\mathrm{Ca}-\mathrm{Sr}-\mathrm{Mn}$ \\
\hline 35 & & $2007-186766$ & 住友電気工業(侏) & $\begin{array}{l}\text { マグネシウム合金ねじの製造方法及びマグネシ } \\
\text { ウムねじ }\end{array}$ & $\mathrm{Mg}-4.0 \sim 10.0 \% \mathrm{Al}-2 \% \mathrm{Zn}-2 \% \mathrm{Mn}-5 \% \mathrm{Si}$ \\
\hline 36 & & $2007-197796$ & アイシン精機侏) & マグネシウム合金拈よび鋳物 & $\begin{array}{l}\mathrm{Mg}-6 \sim 12 \% \mathrm{Al}-0.1 \sim 1.5 \% \mathrm{Mn}-\mathrm{Ca} / \mathrm{Al}: 0.55 \sim 1.0-(>0.5 \% \mathrm{Sr}- \\
>2.5 \% \mathrm{RE} \rightarrow 1 \% \mathrm{Si} \rightarrow 2 \% \mathrm{Sn})\end{array}$ \\
\hline 37 & & $2007-270159$ & リョービ(侏) & 耐クリープマグネシウム合金 & $\begin{array}{l}\mathrm{Mg}-2.5 \sim 6.5 \% \mathrm{Al}-0.3 \sim 3.0 \% \mathrm{Ca}-0.15 \sim 3.0 \% \mathrm{Sn}-0.2 \sim 0.5 \% \mathrm{Mn} \\
(-0.01 \sim 0.3 \% \mathrm{Sr})\end{array}$ \\
\hline 38 & 2008年 & $2008-81773$ & 住友電気工業(株) & マグネシウム合金材及びその製造方法 & $\mathrm{Mg}-2.0 \sim 8.0 \% \mathrm{Al}-0.1 \sim 2.0 \% \mathrm{Zn}-0.01 \sim 2.0 \% \mathrm{Mn}-0.1 \sim 3.0 \% \mathrm{Ca}$ \\
\hline 39 & & 2008-266733 & 株豊田自動織機 & $\begin{array}{l}\text { 鋳造用マグネシウム合金およびマグネシウム合 } \\
\text { 金鋳物 }\end{array}$ & $\mathrm{Mg}-1 \sim 5 \% \mathrm{Cu}-0.1 \sim 5 \% \mathrm{Ca}-1 \sim 3 \% \mathrm{Sn}$ \\
\hline 40 & & $2008-266734$ & 侏豊田自動織機 & $\begin{array}{l}\text { 鋳造用マグネシウム合金拉よびマグネシウム合 } \\
\text { 金鋳物 }\end{array}$ & $\mathrm{Mg}-1 \sim 5 \% \mathrm{Cu}-0.1 \sim 5 \% \mathrm{Ca}-1 \sim 5 \% \mathrm{Ag}$ \\
\hline 41 & 2009年 & $2009-7676$ & (侏)豊田自動織機 & $\begin{array}{l}\text { 鋳造用耐熱マグネシウム合金抢よび耐熱マグネ } \\
\text { シウム合鋳物 }\end{array}$ & $\mathrm{Mg}-1 \sim 15 \% \mathrm{Ca}-3 \sim 10 \% \mathrm{Al}-0.1 \sim 1 \% \mathrm{Mn}$ \\
\hline 42 & & $2009-144215$ & (侏)日本製鋼所 & 耐熱マグネシウム合金材およびその製造方法 & $\mathrm{Mg}-0.5 \sim 4$ at $\% \mathrm{Zn}-0.5 \sim 4$ at $\% \mathrm{Y}-0.5 \mathrm{at} \% \mathrm{Zr}$ \\
\hline 43 & & $2009-149952$ & 本田技研工業(侏) & 耐熱性マグネシウム合金及びその製造方法 & $\mathrm{Mg}-1 \sim 3 \mathrm{at} \% \mathrm{Zn}-1 \sim 3 \mathrm{at} \% \mathrm{Y}-0.01 \sim 0.5 \mathrm{at} \% \mathrm{Zr}$ \\
\hline 44 & & $2009-291332$ & 本田技研工業(怢) & 耐熱性マグネシウム合金 & $\mathrm{Mg}-4.5 \sim 10 \% \mathrm{Al}-0.1 \sim 3 \% \mathrm{Ca}-1 \sim 3 \% \mathrm{RE}-0.3 \sim 1 \% \mathrm{Mn}$ \\
\hline 45 & 2010年 & $2010-77516$ & (侏豊田中央研究所 & マグネシウム合金 & $\begin{array}{l}\mathrm{Mg}-6 \sim 10 \% \mathrm{Al}-2.2 \sim 8.0 \% \mathrm{Ca}-0.1 \sim 1.0 \% \mathrm{Si}-0.05 \sim 1.0 \% \mathrm{Sn}-0.05 \sim \\
1.0 \% \mathrm{Mn}(-1.0 \% \mathrm{Sr},-1.0 \% \mathrm{RE})\end{array}$ \\
\hline 46 & & $2010-90405$ & (株)豊田自動織機 & 耐熱性マグネシウム合金 & $\mathrm{Mg}-\mathrm{Al}-\mathrm{Ca}$ \\
\hline 47 & & 2010-215974 & (制神戸製鋼所 & $\begin{array}{l}\text { 耐力の等方性が優れたた耐熱マグネシウム合金押 } \\
\text { 出材よゔ製造方法 }\end{array}$ & $\mathrm{Mg}-1 \sim 8 \% \mathrm{Y}-1 \sim 8 \% \mathrm{Sm}$ \\
\hline 48 & & $2010-242146$ & (侏)豊田中央研究所 & マグネシウム合金执よびマグネシウム合金部材 & $\mathrm{Mg}-6 \sim 20 \% \mathrm{Al}-3 \sim 9 \% \mathrm{Ca}$ \\
\hline 49 & 2011年 & 2011-99136 & 侏アーレスティ & $\begin{array}{l}\text { 耐熱マグネシウム合金抢よび合金鋳物の製造方 } \\
\text { 法 }\end{array}$ & $\begin{array}{l}\mathrm{Mg}-9.20 \sim 12.6 \% \mathrm{Al}-0.9 \sim 2.0 \% \mathrm{Ca}-0.0005 \sim 0.1000 \% \mathrm{Be}-0.10 \sim \\
0.45 \% \mathrm{Mn}\end{array}$ \\
\hline 50 & & 2011-117064 & (株)神戸製鋼所 & $\begin{array}{l}\text { 疲労強度特性に優れた耐熱マグネシウム合金扔 } \\
\text { よびその耐熱マグネシヴ合金の製造方法並び } \\
\text { にエンジン用耐熱部品 }\end{array}$ & $\mathrm{Mg}-1 \sim 8 \% \mathrm{Y}-1 \sim 8 \% \mathrm{Sm}$ \\
\hline 51 & & 2011-140701 & 本田技研工業(侏) & $\begin{array}{l}\text { 鋳造用マグネシウム合金及びマグネシウム鋳造 } \\
\text { 体の製造方法 }\end{array}$ & $\mathrm{Mg}-1 \sim 3$ at $\% \mathrm{Zn}-1 \sim 3$ at $\% \mathrm{Y}-1 \sim 3$ at $\% \mathrm{Ag}$ \\
\hline 52 & & 2011-208279 & 韓国生産技術研究院 & $\begin{array}{l}\text { 溶湯流動性及び耐熱間亀裂性に優れたマグネシ } \\
\text { ウム系会及びその製造法 }\end{array}$ & $\mathrm{Mg}-$ アルカリ土類金属酸化物 $(\mathrm{CaO}), \mathrm{Ca} \leqq 1.4 \sim 1.7 \times \mathrm{CaO}$ \\
\hline 53 & & $2011-219820$ & (株豊田自動織機 & 耐熱マグネシウム合金 & $\mathrm{Mg}-1 \sim 4 \% \mathrm{Cu}-2 \% \mathrm{Ca}-2 \% \mathrm{Mn}-0.001 \sim 1.5 \% \mathrm{Sc}$ \\
\hline 54 & 2012年 & $2012-57227$ & (株)神戸製鋼所 & 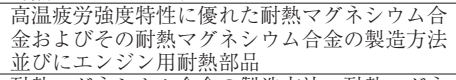 & $\mathrm{Mg}-1.8 \sim 8 \% \mathrm{Y}-1.4 \sim 8.0 \%(\mathrm{Sm}, \mathrm{Nd})-0.5 \sim 2 \% \mathrm{Ho}$ \\
\hline 55 & & 2012-126982 & (侏)豊田中央研究所 & $\begin{array}{l}\text { 耐熱マグネシウム合金の製造方法, 耐熱マグネ } \\
\text { シム合金鋳物およびその製造方法 }\end{array}$ & $\mathrm{Mg}-0.2 \sim 5 \%(\mathrm{Ca}, \mathrm{Si}, \mathrm{Sn})-1 \sim 11 \% \mathrm{Al}-0.5 \sim 5 \mathrm{Zn}-\mathrm{Cu} 0.5$ 以下 \\
\hline 56 & & $2012-197486$ & (濑豊田自動織機 & マグネシウム合金 & $\mathrm{Mg}-12 \%$ 以上 $\mathrm{Al}-0.01 \sim 1 \% \mathrm{Ca}$ \\
\hline 57 & & $2012-214853$ & 国立大学法人熊本大学 & マグネシウム合金及びその製造方法 & $\begin{array}{l}\mathrm{Mg}-0.2 \sim 5.0 \% \mathrm{Zn}-0.5 \sim 5.0 \%(\mathrm{Gd}, \mathrm{Tb}, \mathrm{Tm}, \mathrm{Lu}), \text { 但し } 0.5 \mathrm{Zn}-0.5 \\
\leqq(\mathrm{Gd}, \mathrm{Tb}, \mathrm{Tm}, \mathrm{Lu})\end{array}$ \\
\hline 58 & 2013 年 & 2013-19030 & (制戸畑製作所 & $\begin{array}{l}\text { 耐熱性及び難燃性を有するマグネシウム合金及 } \\
\text { びその製造方法 }\end{array}$ & $\mathrm{Mg}-\mathrm{Al}-0.5 \sim 5 \% \mathrm{Ca}-0.5 \sim 5 \% \mathrm{Si}$ \\
\hline 59 & 2014年 & $2014-1428$ & (㭌)栗本鐵工所 & 耐熱マグネシウム合金 & $\begin{array}{l}\mathrm{Mg}-3.0 \sim 7.0 \% \mathrm{Al}-0.1 \sim 0.6 \% \mathrm{Mn}-1.5 \% \mathrm{Ca} \text { 以上 }-0.4 \% \mathrm{Si} \text { 以上 }(\mathrm{Ca} / \\
\mathrm{Si} \geqq 2.0)\end{array}$ \\
\hline 60 & & 2014-196525 & 株)栗本鐵工所 & 耐熱マグネシウム合金 & $\begin{array}{l}\mathrm{Mg}-3.0 \sim 7.0 \% \mathrm{Al}-0.1 \sim 0.6 \% \mathrm{Mn}-1.5 \sim 2.5 \% \mathrm{Ca}-0.2 \sim 1.3 \% \mathrm{Si}- \\
0.4 \sim 2.3 \% \mathrm{Y}\end{array}$ \\
\hline
\end{tabular}


化を達成することとなった。2003年に公開されたElectron21 マグネシウム合金は，英国 Magnesium Elektron社の Nd, Gdを 主成分とする開発合金であり，200 ${ }^{\circ} \mathrm{C}$ 超える環境で特性を 発揮するマグネシウム合金として紹介されている。ACM522 やAE62-Ca, KUMADAI耐熱マグネシウム合金は，日本で開発 されたマグネシウム合金であり，図12に示すトランスミッ ションケースに採用され，エンジンピストンやターボチャー ジャフィンなどに試作されている。ちなみに, ACM5220記 号はAXM522の表示の方が正確ではないかとの指摘もある。 これらの耐熱マグネシウム合金のほかに中国上海交通大学で 開発されたJDM2,JDM3 なども実用化が検討されているよう である。

1993 年から 2014 年までに日本で公開された耐熱マグネシ ウム合金についての特許例を表 2 に示す。この特許公開状況 を見ると，抜け落ちもあると思われるが 22 年間で 60 件の耐 熱マグネシウム合金特許が公開されており，登録数の多い企 業としてはトヨタ自動車，豊田自動織機，三菱アルミニウム の 3 社が 7 件と多く, 豊田中央研究所 6 件, 本田技術研究所 と宇部興産4件などとなっている。これらの提案された耐熱 マグネシウム合金は，添加成分として主にAl-CaにREや $\mathrm{Si}$, $\mathrm{Al}-\mathrm{Si}$ に $\mathrm{Sr}, \mathrm{RE}$ や $\mathrm{Ca}, \mathrm{Al}-\mathrm{Zn}$ に $\mathrm{Mn}$ や $\mathrm{Ca}, \mathrm{Zn}-\mathrm{RE}$ などを基にさ らに各種成分を添加しているものも見られる。

\section{4.おわりに}

自動車は社会の重要な移動手段として年々進化を遂げてお り，自動運転や衝突防止システムの導入など新装備の装着に より車両重量の増加をもたらす反面，環境対策の強化による 排気ガス削減のための軽量化も喫緊の重要な課題となってい ることは，はじめに紹介した通りである。このため，構造用 金属材料の中で最も軽量なマグネシウム合金を自動車部品と して活用するため，欧米において活発な研究開発が進められ ている。

難燃性マグネシウム合金は，日本が世界に先駆けて考え方 を示した研究開発の成果であり，世界的に注目されている KUMADAI不燃マグネシウム合金は，マグネシウムの沸点で ある $1091^{\circ} \mathrm{C}$ を超えて加熱しても発火しないことが紹介され ている ${ }^{6)}$ 。また，権田金属工業が開発したAZX612マグネシ ウム合金を用いた建築材料が2013 年に国土交通省から不燃 認定を受けている。海外においては，欧州で英国のMEL社 が航空機のシートフレームを軽量化するため米国のFAA で WE43 合金の燃焼試験を実施し，試験条件をクリアすること となった。ちなみに，一般社団法人日本マグネシウム協会
においても「経済産業省委託 平成26年度経済産業省 高 機能 JIS 等整備事業 高機能 JIS 開発 難燃性, 不燃性マグ ネシウム合金の特性評価方法に関するJIS 開発」の一環とし て AZ61, AZ91, AZX311, AMX602, AZX611, AZX612, AZX911, AZX912の8種類のマグネシウム合金についてFAA で試験を 行い，試験条件をクリアしている。

マグネシウム合金の難燃化/不燃化は，使用用途の伸長だ けでなく，マグネシウム合金の溶解作業を画期的に改善する ことが可能になるものと考えられ，粉体は別としてその波及 効果は非常に大きいものと言える。

世界的に多数のマグネシウム合金が開発され実用化されて きたが，わが国で開発された耐熱マグネシウム合金の利用は ほとんどなく，あまり普及していないのが現状である。自動 車の軽量化を図るためにはパワートレイン部品の軽量化も重 要な課題であり，わが国で開発された耐熱マグネシウム合金 の早期な実用化が期待される。

この解説執筆にあたり,「国立研究開発法人新エネル ギー・産業技術総合開発機構（NEDO）の委託事業未来開拓 プログラム（革新的新構造材料等研究開発プロジェクト）」 並びに「経済産業省委託 平成26年度経済産業省 高機能 JIS 等整備事業 高機能 JIS 開発 難燃性，不燃性マグネシウ ム合金の特性評価方法に関するJIS 開発」の成果を参考とし ています。ここに記して謝意を表します。

\section{参 考 文 献}

1) 小池精一, 熟頭和裕, 田中重一, 馬場剛志, 木皮和男 : HONDA R\&D Technical Review, 12-1（2000），167-174

2) 宮下英明, 田雅之, 坂田正保, 早川幸宏, 松村定晴: HONDA R\&D Technical Review, 14-2（2002），135-142.

3）日本マグネシウム協会編：マグネシウム技術便覧，（2000） 159-163.

4) 秋山 茂: 鋳物, 66 (1994), 38-42.

5) 上田光二, 谷州 博, 中村 喬 : 近畿車輛技法, 14-10 (2007), 40-42.

6) 河村能人：軽金属, 65 (2015), 466-471.

7）上田光二：近畿車輌技報, 11（2004）, 38-41.

8) T. Marker: Evaluating the Flammability of Various Magnesium Alloys During Laboratory- and Full-Scale Aircraft Fire Tests, FAA Final Report, DOT/FAA/AR-11/3, 1 (2013)

9) T. Marker: Development of a Laboratory-Scale Flammability Test for Magnesium Alloys Used in Aircraft Seat Construction, FAA FinalReport, DOT/FAA/TC-13/52, 2 (2014)

10) The FAA Fire Safety Branch Document: Aircraft Materials Fire Test Handbook-DOT/FAA/AR-00/12, Chapter 25.

11) S. K. Kim, J. K. Lee, H. Cho, H. H. Jo, W. Ha and Y. J. Kim: Magnesium Technology 2005, 285-289.

12) B. S. You, W. W. Park and I. S. Chung: Scr. Mater., 42 (2000), 10891094. 